Notes \& Comments

\title{
Protonectarina sylveirae (Hymenoptera: Vespidae): first report preying Bedellia somnulentella (Lepidoptera: Bedelliidae) in Brazil
}

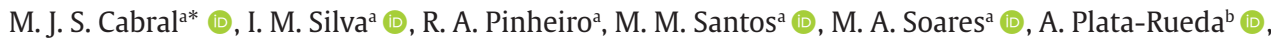

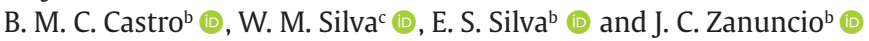 \\ aprograma de Pós-graduação em Produção Vegetal, Laboratório de Entomologia, Universidade Federal dos Vales do Jequitinhonha e \\ Mucuri - UFVJM, Diamantina, MG, Brasil \\ bDepartamento de Entomologia, Instituto de Biotecnologia Aplicada à Agropecuária - BIOAGRO, Universidade Federal de Viçosa - UFV, Viçosa, \\ MG, Brasil \\ 'Departamento de Engenharia Florestal, Universidade Federal de Viçosa - UFV, Viçosa, MG, Brasil
}

The cultivation of sweet potato, Ipomoea batatas Lam (Solanales: Convolvulaceae), is important for food security (FAOSTAT BRAZIL, 2021). Roots and vines of sweet potato are food for humans and animals and industrial raw materials (Schoenherr et al., 2019). Sweet potato plants produce phytoalexins, latex and terpenoids with antibiosis effect, but insect pests can damage this plant (Santos et al., 2018a). The leaf-mining microlepidoptera Bedellia somnulentella (Zeller, 1847) (Lepidoptera: Bedelliidae) is native to Eurasia and one of the main insect pests of the aerial part of sweet potato plants (Steyn et al., 2020; Santos et al., 2021).

Bedellia somnulentella feeds on the leaf mesophyll reducing photosynthesis and, consequently, the development of tuberous roots of sweet potato plants (Santos et al., 2018b). In addition, lesions caused by $B$. somnulentella facilitate pathogenic fungi and bacteria entering leaf tissues, reducing sweet potato yield (Cabrera Asencio et al., 2008). This invasive pest was reported on the African, American, Asian, European and Oceania continents (Parrella and Kok, 1977; Fatah et al., 2014). In South America, it was registered in Peru and Brazil (Nhm, 1914; Santos et al., 2018b, 2021). Alternatives for pest management in sweet potato crops are being sought, increasing the importance of identifying native natural enemies of B. somnulentella.

Vespidae are predatory and entomophagous insects that are important in biological control preying on Diptera, Hemiptera, other Hymenoptera and mainly Lepidoptera species (Brigatte et al., 2011). The paper wasp Protonectarina sylveirae (Saussure) (Hymenoptera: Vespidae), the only species of the genus Protonectarina Ducke, is aggressive, forming colonies with large populations (Jacques et al., 2018) and has been reported in Argentina, Brazil and Paraguay (Silva et al., 2018). In Brazil, P. sylveirae has been reported in Bahia, Ceará, Espírito Santo, Goiás, Mato Grosso do Sul, Minas Gerais, Paraná, Piauí, Rio de Janeiro, Rio Grande do Norte, Rio Grande do Sul, Santa Catarina, and São Paulo states (Henrique-Simões et al., 2016;
Silva et al., 2018). Protonectarina sylveirae occurs in the Atlantic Rainforest, Cerrado (Savanna) and Caatinga, a type of desertic vegetation found exclusively in the northeast Brazil (Silva et al., 2018).

Protonectarina sylveirae builds elaborate and polygenic nests by swarming and its social characteristics are complex (Picanço et al., 2011; Pereira et al., 2013). Social wasps (Hymenoptera: Vespidae: Polistinae) actively participate in the trophic balance in natural ecosystems and in the biological control of agricultural pests (Ferreira et al., 2020). Due to their social behavior, these wasps are abundant and participate in food chains (Picanço et al., 2010). Furthermore, social wasps preferentially feed on immature lepidopterans (Prezoto et al., 2019). Damage caused by Lepidoptera caterpillars is one of the main phytosanitary problems in Brazilian plantations with significant economic losses (Bueno et al., 2017). Wasp predation is a significant mortality factor (Soares et al., 2019) and should be included in pest management programs (Bacci et al., 2019). The objective was to record the predation of $B$. somnulentella caterpillars and pupae by $P$. sylveirae on sweet potato plants.

Wasp specimens were observed preying on $B$. somnulentella caterpillars and pupae on sweet potato in the field at different times in the horticulture sector of the Universidade Federal dos Vales do Jequitinhonha e Mucuri (UFVJM) in Diamantina, Minas Gerais, Brazil (altitude $1387 \mathrm{~m}, 18^{\circ} 10^{\prime} \mathrm{S}$ and $43^{\circ} 30^{\prime} \mathrm{W}$ ). A nest and individuals of this wasp were collected, photographed and sent to the taxonomist Prof. Marcos Magalhães de Souza, from the Federal Institute of Education, Science and Technology of Southern Minas Gerais, Brazil, for identification.

The wasps were identified as Protonectarina sylveirae (Saussure, 1854) (Hymenoptera: Vespidae). The body length of $P$. sylveirae is short (less than $1.0 \mathrm{~cm}$ long), with black coloration and yellow marks and stripes on the body (Figure 1A). The identification of $P$. sylveirae was based, on a lateral and frontal view of the head, on the lateral

*e-mail: jessica.cabral@ufvjm.edu.br

Received: September 28, 2021 - Accepted: January 13, 2022 


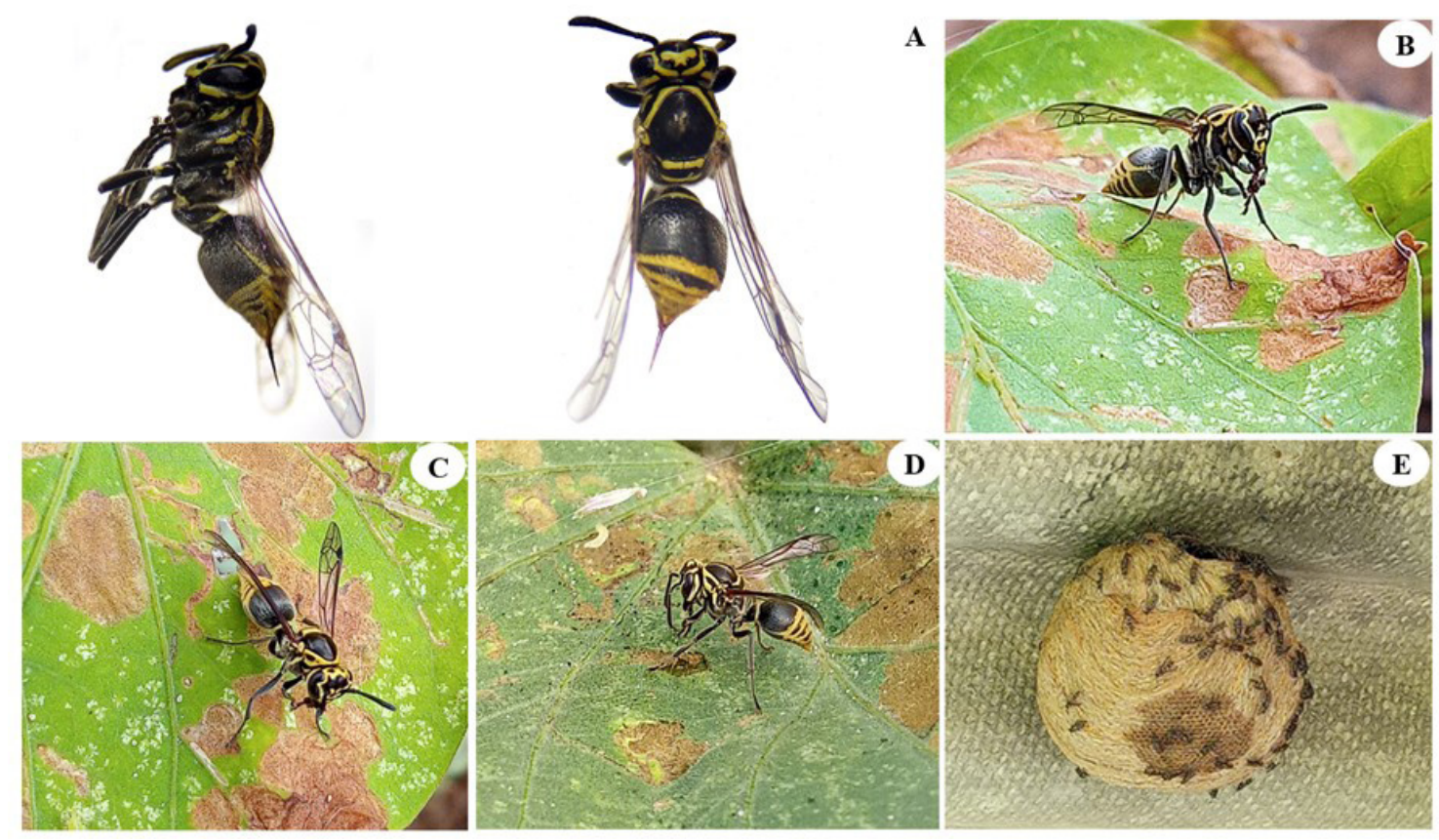

Figure 1. Adults (A), predation of Bedellia somnulentella (Lepidoptera: Bedelliidae) caterpillars and pupae (B, C), individual of Protonectarina sylveirae (Hymenoptera: Vespidae) tearing leaf mines looking for caterpillars of different instars (D) of B. somnulentella and nest (E), of this wasp, built in civil construction in Diamantina, Minas Gerais state, Brazil.

ocellus separated by a distance almost equal to that of an ocellus to the eye, metasomal segment I non-petiolate in a dorsal view and eyes with short bristly bristles (Richards, 1978; Carpenter and Marques 2001).

Adults of $P$. sylveirae preyed on all $B$. somnulentella caterpillars and pupae on sweet potato plants in the field by feeding and carrying many of these prey to the nest within a few hours (Figure $1 \mathrm{~B}, \mathrm{C}$ ). The predation of B. sommulentella caterpillars and pupae on sweet potato plants suggests the importance of $P$. sylveirae in the biological control of this pest. Protonectarina sylveirae is also important for the biological control of the leafminers Leucoptera coffeella (Guérin-Méneville, 1842) (Lepidoptera: Lyonetiidae) on coffee plants and Tuta absoluta (Meyrick, 1917) (Lepidoptera: Gelechiidae) in open-field tomato crops in Brazil (Bacci et al., 2019).

The generalist and voracious feeding habit of $P$. sylveirae is common in social wasps (Brigatte et al., 2011), killing many preys such as caterpillars in short periods (Ghoneim, 2014). Protonectarina sylveirae caused $99.08 \%$ of the mortality of T. absoluta caterpillars (Bacci et al., 2019). Biological control by social wasps (Vespidae: Polistinae) has been reported for Agelaia multipicta (Haliday, 1836), Agelaia vicina (Saussure, 1854), Apoica pallens (Fabricius, 1804), Brachygastra lecheguana (Latreille, 1824), Parachartergus fraternus (Griboldo, 1892), Polistes ferreri (Saussure, 1853), Polistes versicolor (Olivier, 1971), Polybia bifasciata Saussure, 1854, Polybia chrysothorax (Lichtenstein, 1796), Polybia diguetana (Buysson, 1905), Polybia fastidiosuscula (Saussure, 1854), Polybia ignobilis (Haliday, 1836), Polybia jurinei Saussure, 1854, Polybia occidentalis (Olivier, 1971),
Polybia platycephala Richards, 1978, Polybia punctata du Buysson, 1907, Polybia sericea (Olivier, 1971), and Protonectarina sylveirae preying on leafmining insects such as L. coffeella, T. absoluta and Plutella xylostella (Linnaeus, 1758)(Lepidoptera: Plutellidae)(Ghoneim, 2014; Tomazella et al., 2018). The social behavior of wasps, with many individuals per colony, increases the efficiency of these insects in the biological control, including P. sylveirae preying on $B$. somnulentella.

Individuals of $P$. sylveirae prey on caterpillars of different instars and B. somnulentella pupae inside or outside leaf mines (Figure 1D). This predation behavior is similar to that reported for this wasp preying on caterpillars and pupae of T. absoluta (Picanço et al., 2011; Bacci et al., 2019). Mines, in the leaves, protect T. absoluta caterpillars against P. sylveirae, but this wasp located these prey inside them, removed and preyed on them (Bacci et al., 2019).

Migrating caterpillars and prepupa of B. sommulentella are exposed on the leaves and are the first predated. In addition, $P$. sylveirae located leaves mined with $B$. somnulentella caterpillars, tore the leaf epidermis with its chewing mouthparts and withdrew them from the mines. The initial predation on exposed caterpillars is due to the easiness of attacking them, as feeding on the leaf mesophyll provides some protection, through the upper and lower epidermis of the leaf, against $P$. sylveirae.

The behavior of locating and removing caterpillars in mines is typical in species of the Vespidae family such as B. lecheguana, Mischocyttarus drewseni (Sausurre, 1857), Mischocyttarus labiatus (Fabricius, 1804), Mischocyttarus latior (Fox, 1898), Polistes ferreri (Saussure, 1853), Polistes 
simillimus (Zikán, 1951), Polistes versicolor, Polistes satan (Bequaert, 1940), Polybia fastidiosuscula, Polybia ignobilis, Polybia jurinei, Polybia occidentalis, Polybia paulista (R. Von. Ihering, 1896), Polybia sericea and Protopolybia sedula (Saussure, 1854) (Ghoneim, 2014; Jacques et al., 2018).

The nest shape of $P$. sylveirae, found 200 meters away from the sweet potato plantation, attached to civil construction, is oval cylindrical with thousands of individuals with a small upper opening (Figure 1E). The cylindrical oval $P$. sylveirae nest morphology is not a standard (Jacques et al., 2015), as this wasp builds nests in varying shapes and sizes, from small with simple to large and complex structures (Henrique-Simões et al., 2016). The finding of the $P$. sylveirae nest attached to civil construction confirms the diversity of nesting sites for this wasp, including large, perennial tree species, usually suspended from a branch (Soares et al., 2019), near civil constructions (Somavilla et al., 2017). The materials used by $P$. sylveirae to build nests are mainly vegetable fibbers mixed with water and salivary secretion from the mandibular glands, resulting in a product similar to paper, which gave rise to its common name (Somavilla et al., 2012). The nest of $P$. sylveirae is of the fragmocytic type with an initial comb fixed to the substrate and covered by an envelope or by a combination of new cells in the lower part of the first envelope, surrounded by a second one (Henrique-Simões et al., 2016). Then, new combs are built in an identical process, with each envelope having an entrance to the respective combs (HenriqueSimões et al., 2016).

The high population size of $P$. sylveirae is due to its swarm and polygyny strategy (more than one queen per nest), reducing the risk of losses and increasing the life span of the colony, whose females are philopatric (Biondi et al., 2013; Locher et al., 2014). The number of $P$. sylveirae individuals per nest can be thousands, including workers, males and queens (Arab et al., 2010), as reported for approximately 43,000 individuals, including 500 queens and large numbers of eggs, larvae and pupae in a nest of this wasp in São José do Rio Preto, São Paulo, Brazil (Tanaka Junior et al., 2010). The presence of males in P. sylveirae colonies indicates the beginning of the flocking period for the foundation of new nests (Tanaka Junior et al., 2010).

Identifying $P$. sylveirae preying on B. somnulentella caterpillars and pupae on sweet potato plants in Brazil is important for the integrated management of this pest. This is the first time this association has been registered and increases the need to preserve wasp colonies near cultivated areas to reduce $B$. somnulentella populations in conservative biological control.

\section{Acknowledgements}

To Dr. Marcos Magalhães de Souza for identifying the wasp species. To "Coordenação de Aperfeiçoamento de Pessoal de Nível Superior (CAPES), Conselho Nacional de Desenvolvimento Científico e Tecnológico (CNPq), Fundação de Amparo à Pesquisa do Estado de Minas Gerais (FAPEMIG)" and "Programa Cooperativo sobre Proteção
Florestal (PROTEF) do Instituto de Pesquisas e Estudos Florestais (IPEF)" for support.

\section{References}

ARAB, A., CABRINI, I. and ANDRADE, C.F.S., 2010. Diversity of polistinae wasps (Hymenoptera, Vespidae) in fragments of Atlantic Rain Forest with different levels of regeneration in southeastern Brazil. Sociobiology, vol. 56, no. 2, pp. 515-525.

BACCI, L., SILVA, É.M., SILVA, G.A., SILVA, L.J., ROSADO, J.F., SAMUELS, R.I. and PICANÇO, M.C., 2019. Natural mortality factors of tomato leafminer Tuta absoluta in open-field tomato crops in South America. Pest Management Science, vol. 75, no. 3, pp. 736-743. http://dx.doi.org/10.1002/ps.5173. PMid:30101575.

BIONDI, A., ZAPPALÀ, L., STARK, J.D. and DESNEUX, N., 2013. Do biopesticides affect the demographic traits of a parasitoid wasp and its biocontrol services through sublethal effects? PLoS One, vol. 8, no. 9, pp. e76548. http://dx.doi.org/10.1371/ journal.pone.0076548. PMid:24098793.

BUENO, R.C.O.F., RAETANO, C.G., JUNIOR, J.D. and CARVALHO, F.K., 2017. Integrated management of soybean pests: the example of Brazil. Outlooks on Pest Management, vol. 28, no. 4, pp. 149153. http://dx.doi.org/10.1564/v28_aug_02.

BRIGATTE, P., CURY, Y., DE SOUZA, B.M., BAPTISTA-SAIDEMBERG, N.B., SAIDEMBERG, D.M., GUTIERREZ, V.P. and PALMA, M.S., 2011. Hyperalgesic and edematogenic effects of peptides isolated from the venoms of honeybee (Apis mellifera) and neotropical social wasps (Polybia paulista and Protonectarina sylveirae). Amino Acids, vol. 40, no. 1, pp. 101-111. http://dx.doi. org/10.1007/s00726-010-0512-8. PMid:20177946.

CARPENTER, J.M. and MARQUES, O.M., 2001. Contribuição ao estudo dos vespídeos do Brasil (Insecta, Hymenoptera, Vespoidea, Vespidae). Publicações Digitais, vol. 2, pp. 1-147.

CABRERA ASENCIO, I., SEGARRA CARMONA, A.E. and VELEZ, A.L., 2008. Bedellia somnulentella (Zeller) (Lepidoptera: Lyonetiidae): Una nueva plaga de la batata/Ipomoea batatas (1.) introducida en Puerto Rico. The Journal of Agriculture of the University of Puerto Rico, vol. 92, no. 1, pp. 115-118.

FATAH, F., JAMIALAHMADI, M., ASADI, G. and MOODI, S., 2014. First report of Bedellia somnulentella (Lep.: Bedelliidae) from Iran. Journal of Entomological Society of Iran, vol. 34, no. 2, pp. 13-14.

FAOSTAT BRAZIL; 2021 [viewed 15 July 2021]. Sweet potatoes, production quantity (tons). IOP Publishing Physics Web. Available from: https://www.factfish.com/statisticcountry/brazil/ sweet\%2520potatoes\%2 C\%2520production\%2520quantity.

FERREIRA, J.V.A., STORCK-TONON, D., DA SILVA, R.J., SOMAVILLA, A., PEREIRA, M.J.B. and DA SILVA, D.J., 2020. Effect of habitat amount and complexity on social wasps (Vespidae: Polistinae): implications for biological control. Journal of Insect Conservation, vol. 24, no. 4, pp. 613-624. http://dx.doi.org/10.1007/s10841020-00221-7.

GHONEIM, K., 2014. Predatory insects and arachnids as potential biological control agents against the invasive tomato leafminer, Tuta absoluta Meyrick (Lepidoptera: Gelechiidae), in perspective and prospective. Journal of Entomology and Zoology Studies, vol. 2, no. 2, pp. 52-71.

HENRIQUE-SIMÕES, M., CUOZZO, M.D. and FRIEIRO-COSTA, F.A., 2016. Social wasps of Unilavras/Boqueirão Biological Reserve, Ingaí, state of Minas Gerais, Brazil. Check List, vol. 7, no. 5, pp. 656-667. http://dx.doi.org/10.15560/7.5.656.

JACQUES, C.G., SOUZA, M.M., COELHO, H.J., VICENTE, L.O. and SILVEIRA, L.C.P., 2015. Diversity of social wasps (Hymenoptera: 
Vespidae: Polistinae) in an agricultural environment in Bambuí, Minas Gerais, Brazil. Sociobiology, vol. 62, no. 3, pp. 439-445. http://dx.doi.org/10.13102/sociobiology.v62i3.738.

JACQUES, G.C., PIKART, T.G., SANTOS, V.S., VICENTE, L.O. and SILVEIRA, L.C.P., 2018. Niche overlap and daily activity pattern of social wasps (Vespidae: Polistinae) in kale crops. Sociobiology, vol. 65, no. 2, pp. 312-319. http://dx.doi.org/10.13102/sociobiology. v65i2.2670.

LOCHER, G.A., TOGNI, O.C., SILVEIRA, O.T. and GIANNOTTI, E., 2014. The social wasp fauna of a riparian forest in southeastern Brazil (Hymenoptera, Vespidae). Sociobiology, vol. 61, no. 2, pp. 225233. http://dx.doi.org/10.13102/sociobiology.v61i2.225-233.

NATURAL HISTORY MUSEUM - NHM, Specimen record from the collection in the Natural History Museum (London, UK). London, UK: Natural History Museum, 1914.

PARRELLA, M.P. and KOK, L.T., 1977. The development and reproduction of Bedellia somnulentella on Hedge Bindweed and Sweet Potato. Annals of the Entomological Society of America, vol. 70, no. 6, pp. 925-928. http://dx.doi.org/10.1093/aesa/70.6.925.

PEREIRA, A.I.A., ANDRADE, G.S., ZANUNCIO, J.C., PENTEADO-DIAS, A.M. and SERRÃO,J.E., 2013. A brief observation of morphological and behavioral similarities between the Ichneumonidae wasp Cryptanura sp. and its presumed mimic, Holymenia clavigera (Heteroptera: Coreidae), in Brazil. Brazilian Journal of Biology = Revista Brasileira de Biologia, vol. 73, no. 4, pp. 903-909. http://dx.doi.org/10.1590/S1519-69842013000400029. PMid:24789409.

PICANÇO, M.C., BACCI, L., QUEIROZ, R.B., SILVA, G.A., MIRANDA, M.M.M., LEITE, G.L.D. and SUINAGA, F.A., 2011. Social wasp predators of Tuta absoluta. Sociobiology, vol. 58, no. 3, pp. 621-633.

PICANÇO, M.C., DE OLIVEIRA, I.R., ROSADO, J.F., DA SILVA, F.M., DA COSTA GONTIJO, P. and DA SILVA, R.S., 2010. Natural biological control of Ascia monuste by the Social Wasp Polybia ignobilis (Hymenoptera: vespidae). Sociobiology, vol. 56, no. 1, pp. 67-76.

PREZOTO, F., MACIEL, T.T., DETONI, M., MAYORQUIN, A.Z. and BARBOSA, B.C., 2019. Pest control potential of social wasps in small farms and urban gardens. Insects, vol. 10, no. 7, pp. 192. http://dx.doi.org/10.3390/insects10070192. PMid:31261790.

RICHARDS, O.W., 1978. The social wasps of the Americas (excluding the Vespinae). London: British Museum of Natural History, pp. 580.

SANTOS, E.A.D., ANDRADE JÚNIOR, V.C.D., VIANA, D.J.S., SANTOS, A.A.D., SILVA, A.J.M.D. and FIALHO, C.M.T., 2018a. Sensitivity of sweet potato genotypes to clomazone and weed interference. Revista Caatinga, vol. 31, no. 2, pp. 352-359. http://dx.doi. org/10.1590/1983-21252018v31n211rc.

SANTOS, M.M., SOARES, M.A., SILVA, I.M., FONTES, P.C.R. and ZANUNCIO, J.C., 2018b. First record of the sweet potato pest Bedellia somnulentella (Lepidoptera: Bedelliidae) in Brazil. The
Florida Entomologist, vol. 101, no. 2, pp. 315-316. http://dx.doi. org/10.1653/024.101.0224.

SANTOS, M.M., GOMES, G.N., PINTO, T.A.A., SILVA, I.M., LEITE, G.L.D. and SOARES, M.A., 2021. Geographic distribution of the Ipomoea batatas (Convolvulaceae) pest, Bedellia somnulentella (Zeller) (Lepidoptera: Bedelliidae), in Minas Gerais state, Brazil.Journal of Plant Diseases and Protection, vol. 128, no. 2, pp. 617-621. http://dx.doi.org/10.1007/s41348-020-00390-2.

SCHOENHERR, A.P., RIZZO, E., JACKSON, N., MANOSALVA, P. and GOMEZ, S.K., 2019. Mycorrhiza-induced resistance in potato involves priming of defense responses against Cabbage looper (Noctuidae: lepidoptera). Environmental Entomology, vol. 48, no. 2, pp. 370-381. http://dx.doi.org/10.1093/ee/nvy195. PMid:30715218.

SILVA, M., NOLL, F.B. and CASTRO, A.C.M.C., 2018. Phylogeographic analysis reveals high genetic structure with uniform phenotypes in the paper wasp Protonectarina sylveirae (Hymenoptera: vespidae). PLoS One, vol. 13, no. 3, pp. e0194424. http://dx.doi. org/10.1371/journal.pone.0194424. PMid:29538451.

SOARES, W.S., JUNIOR, S.D.M.D., SILVA, I.W., RUEDA, A.P., SOUZA, E.A. and FERNANDES, F.L., 2019. Physiological selectivity of insecticides from different chemical groups and cuticle thickness of Protonectarina sylveirae (Saussure) and Brachygastra lecheguana (Latreille). Sociobiology, vol. 66, no. 2, pp. 358-366. http://dx.doi.org/10.13102/sociobiology.v66i2.3478.

SOMAVILLA, A., DE OLIVEIRA, M.L. and RAFAEL, J.A., 2017. Social wasps (Vespidae: Polistinae) from two national parks of the Caatinga biome, in Brazil. Sociobiology, vol. 64, no. 3, pp. 334-338. http://dx.doi.org/10.13102/sociobiology.v64i3.1593.

SOMAVILLA, A., OLIVEIRA, M.L. and SILVEIRA, O.T., 2012. Guia de identificação dos ninhos de vespas sociais (Hymenoptera, Vespidae, Polistinae) na Reserva Ducke, Manaus, Amazonas, Brasil. Revista Brasileira de Entomologia, vol. 56, no. 4, pp. 405414. http://dx.doi.org/10.1590/S0085-56262012000400003.

STEYN, L.A.I., GEERTSEMA, H., MALAN, A.P. and ADDISON, P., 2020. A review of leaf-mining insects and control options for their management, with special reference to Holocacista capensis (Lepidoptera: Heliozelidae) in vineyards in South Africa. South African Journal of Enology and Viticulture, vol. 41, no. 2, pp. 218232. http://dx.doi.org/10.21548/41-2-4081.

TANAKA JUNIOR, G.M., SOLEMAN, R.A. and NOLL, F.B., 2010. Morphological and physiological variation between queens and workers of Protonectarina sylveirae (de Saussure) (Hymenoptera, Vespidae, Epiponini). Revista Brasileira de Entomologia, vol. 54, no. 1, pp. 104-109. http://dx.doi.org/10.1590/S008556262010000100013.

TOMAZELLA, V.B., JACQUES, G.C., LIRA, A.C. and SILVEIRA, L.C.P., 2018. Visitation of social wasps in Arabica coffee crop (Coffea arabica L.) intercropped with different tree species. Sociobiology, vol. 65, no. 2, pp. 299-304. http://dx.doi.org/10.13102/sociobiology. v65i2.1397. 